\title{
Yıkıcı Liderlik ile Algılanan Örgütsel Engel Arasındaki İlişkinin İncelenmesi
}

\author{
DOI: 10.26466/opus.843064 \\ $*$ \\ Münevver Çetin* - Muammer MARAL** \\ * Prof. Dr., Marmara Üniversitesi,İstanbul /Türkiye \\ E-Posta: mcetin@marmara.edu.tr \\ ORCID: $\underline{0000-0002-1203-9098}$ \\ **Dr. Öğrencisi Marmara Üniversitesi, İstanbul/Türkiye \\ E-Posta: muammermaral@hotmail.com \\ ORCID: $\underline{0000-0002-2055-5711}$
}

\section{Öz}

Bu çalışmanın amacı okul yöneticilerinin yıkıcı liderlik davranışları ile öğretmenlerin algilarına göre örgütsel engel arasındaki ilişkiyi belirlemektir. Bu amaçla çalışmada okul yöneticilerinin yıkıcı liderlik davranışlarını ne sıklıkla sergiledikleri, yıkıcı liderlik ve algılanan örgütsel engel değişkenleri ile okul yöneticilerinin cinsiyeti, okul türü, okuldaki personel sayısı, öğretmenlerin hizmet yılı değişkenleri arasındaki ilişki ve bunların yanında yıkıcı liderlik alt boyutlarının algılanan örgütsel engelleri ne derece yordadı̆̆̆ ve yıkıcı liderlik ile algılanan örgütsel engel arasındaki ilişki incelenmiştir. İlişkisel modelde olan bu araştırma Sakarya ilindeki okul öncesi, ilkokul, ortaokul ve liselerde görev yapan toplam 325 öğretmen ile gerçekleştirilmiştir. Verilerin toplanmasında "Yikıcı Liderlik Ölçeği" ile "Alg̨lanan Örgütsel Engel Ölçeği" kullanılmıştır. Araştırma bulgularında okul yöneticilerinin yıkıcı liderlik davranışlarını sergileme düzeyinin düşük olduğu belirlenmiş ve yıkıcı liderlik ile okuldaki personel sayısı ve öğretmenlerin hizmet yılı arasında anlamlı farklılık tespit edilmiştir. Öğretmenlerin algılarına göre algılanan örgütsel engel düzeyinin düşük olduğu belirlenmiş, algılanan örgütsel engel ile okul türü ve okuldaki personel sayısı değişkenleri arasında anlamlı farklılık tespit edilmiştir. Yikıcı liderlik alt boyutlarından olan "liderlik için yetkin olmamak" ve "adam kayırma" boyutlarının algılanan örgütsel engelleri anlamlı olarak yordadığı ve yıkıcı liderlik ile algilanan örgütsel engel arasında pozitif yüksek düzeyde ilişki tespit edilmiştir.

AnahtarKelimeler: Liderlik, Yıkıcıliderlik, Örgütsel engel. 


\title{
Analysis of the Relationship Between the Destructive Leadership and the Perceived Organizational Obstacles
}

\begin{abstract}
The aim of this study is to determine the relationship between destructive leadership behaviors of school administrators and organizational obstacle according to teachers' perceptions. For this purpose, in this study, it has been examined that how often school administrators perform destructive leadership behaviors, the relationship between both destructive leadership and perceived organizational obstacle, and gender of school administrators, type of school, number of staff at school, tenure of teachers, in addition, the extent to which destructive leadership sub-dimensions predict perceived organizational obstacle and the relationship between these two concepts. With the correlational method, this research was conducted with 325 teachers working in pre-school, primary, secondary and high schools in Sakarya. "Destructive Leadership Scale" and "Perceived Organizational Obstruction Scale" were used to collect data. In the research findings, it was determined that the level of performing destructive leadership of school administrators was low and significant difference was found between the destructive leadership and the number of school staff and tenure of teachers. According to the teachers' perceptions, the level of perceived organizational obstacle was determined to be low, and there was a significant difference between the perceived organizational obstacle and the type of school and the number of staff at school. It was determined that the dimensions of "inadequate leadership skills" and "nepotism (favoritism)" which are destructive leadership sub-dimensions, significantly predict the perceived organizational obstacles, and a high level of positive relationship was found between destructive leadership and perceived organizational obstacle.
\end{abstract}

Keywords: Leadership, Disruptive leadership, Organizational obstruction. 


\section{Giriş}

İnsanlar, sosyal varlık olmaları ve bunun sağladığı avantajlardan dolayı bir arada yaşama eğilimindedir. İnsanların bir arada yaşaması çeşitli grup ve toplulukların ortaya çıkmasına neden olmuştur. Liderlik de bu grupların ve toplulukların yönetilmesi ihtiyacından ortaya çıkmıştır. Bu durum hem grupların ve toplulukların yönetilmesi gerektiğinin hem de grup ve toplulukların yönetilme ihtiyacının doğal bir sonucudur (Erkutlu, 2014).

Liderlik; psikoloji, tarih, siyaset bilimi, sosyoloji, yönetimi bilimi gibi sosyal bilimlerin konusu olmuştur (Hughes, Ginnett ve Gordon, 1999; Çelik, 2015). Liderlik konusunda 3000' den fazla empirik araştırma yapılmış, yüz binleri aşan çeşitli türde çalışma yapılmıştır (Çelik, 2015; Barutçugil, 2014). Günümüzde liderliğe ilişkin çok fazla sayıda tanım, teori ve yaklaşım bulunmaktadır (Barutçugil, 2014). Liderlik kavramına geçmişten günümüze kadar yönetim işlevinin olduğu her alanda birçok anlam verilmesine rağmen liderlik kavramı her zaman var olmuş ve önemini yitirmemiştir (Çelik, 2015).

Liderlik üzerine ilk ciddi çalışmalar 20. yüzyıla gelindiğinde başlamıştır. Liderlik araştırmalarının birçoğu liderlerin etkililiğine etki eden etmenler üzerinedir. Sosyal bilimciler, bir liderin izleyenlerini nasıl etkilediğini, etkileme düzeylerini, görevlerini nasıl ve ne düzeyde gerçekleştirdiklerini ve tüm bunları gerçekleştirmelerini sağlayan özellikleri, davranışları, güç kaynaklarını ve yetenekleri belirlemeye, örgütlerde neden bazı liderlerin ön plana çıtığını ve liderin davranışlarını belirleyen etmenleri belirlemeye çalışmıştır (Yukl, 2018). 1930'lu yıllarından sonunda “Özellikler Kuramı" ile başlayan ilk ciddi çalışmalardan bu yana liderlerin olumlu özellikleri üzerinde durulmuş, liderliğin "karanlık yönü" olan yıkıcı liderlik üzerine yeterince yoğunlaşılmamıştır (Celep, 2014). Örgütlerde yıkıcı liderliğin zararlı, olumsuz etkilerine yönelik çalışma sayısı ve buna yönelik geliştirilen teori çok azdır (Tepper, 2000). Yapılan araştırmaların çoğu yapıcı, başarılı ve etkili liderlik hakkındadır (Kelloway, Mullen ve Francis, 2006).

Yıkıcı liderlik, çalışanlara ve örgüte yönelik olan, sistematik ve tekrarlanan bir şekilde, kasıtlı veya kasıtsız olarak gerçekleştirilen zararlı davranışları ifade etmektedir.Yapılan araştırmalarda çalışanların işlerinden 
yılma davranışı sergiledikleri, çalışanların tolerans göstermeyen işverenlere maruz kaldıkları (Lombardo ve McCall, 1984; Zapf, Einersan, Hoel ve Vartia, 2003), yıkıcı liderliğin çalışanların iş tatmin düzeylerini olumsuz etkilediği ve işlerini aksatma davranışı ortaya koymalarına sebep olduğu, çalışanların örgütsel bağlılık düzeyini düşürdügüu, çalışanların işten ayrılma eğilimlerini artırdığı (Sezici, 2015), kaynakların kötüye kullanılmasına neden olduğu (Çetin, 2019) ortaya çıkmıştır. Tüm bu çalışmalar liderlerin bahsedilen olumlu davranışlarının yanında aktif olarak yıkıcı davranışlar da sergilediğini ortaya koymaktadır.

$\mathrm{Bu}$ çalışmada yıkıcı liderlik ile örgütsel engeller arasındaki ilişki incelenecektir. Yıkıcı liderlik davranışlarının bireylerin mesleki ve kişisel gelişimlerini engelleyen, refah düzeylerinin ve iş performanslarının düşmesine sebep olan, başarıya ulaşmalarını ve motivasyonlarını olumsuz etkileyen, stres düzeyinin artması gibi daha birçok olumsuz duruma neden olan örgütsel engeller ile ilişkisi saptanmaya çalışılacaktır. Çalışanların yıkıcı liderlik davranışlarına maruz kalıp kalmadıkları, kalıyorlarsa düzeyinin ne olduğu ve bu davranışların örgüt üyelerinin örgütsel engellerle karşılaşmalarına neden olup olmadığı, oluyorsa ne düzeyde olduğu sorgulanacaktır.

\section{Liderlik}

Liderlik kavramı üzerine birçok araştırma yapılmış ve birçok tanımlamada bulunulmuştur. Dubrin (1995)'e göre liderlik, örgütün amaçlarına ulaşmalarını sağlamak için çalışanları teşvik etme ve onlara güven verme yeteneğidir. Shackleton (1995)'a göre ise liderlik, örgütün amaçlarına ulaşmalarını sağlamak için birey veya grupları bu amaçlar doğrultusunda motive eden, onların çalışmalarını etkileme ve yönlendirme yetisine sahip kişidir.

Liderlik üzerine yapılan araştırmaların büyük çoğunluğu liderlerin olumlu özellikleri üzerine kuruludur (Celep, 2014). Bu çalışmalarda liderlerin sahip olduğu veya olması gereken özellikleri, etkili liderlik çeşitleri, liderin sahip olması gereken yönetim türleri, çalışanlarına karşı yaklaşım tarzl, liderin örgüt içindeki rolü incelenirken, olumsuz etki oluşturan liderlik davranışı üzerinde gerektiği kadar durulmamıştır (Gündüz ve De- 
dekorkut, 2014). Karizma konusundaki tartışmaların bir kısmı hariç olmak üzere toplum bilimiyle uğraşanlar genellikle liderlik kavramının karanlık yönlerinden kaçınmışlardır. Bu konuyla ilgili ayrıntılı bir çalışma yapıldığında yıkıcı liderliğin tam olarak tanımlanamadığı görülecektir. Lider ve liderlik kavramı birçok olumlu özelliği içerisinde barındırdığı gibi örgüt ve bireyler için hayati öneme sahip olumsuz özellikleri de içermektedir. Liderlik ile ilgili literatürde özellikle ilk zamanlarda liderlerin her zaman iyi, hatta insanüstü özellikleri barındırdığı kabul edilmiş ve belirli özellikleri barındırmayan kişilerin iyi lider olamayacağ 1 düşünülmüştür (Kellerman, 2004; Thoroughgood, Hunter ve Sawyer, 2011). Ancak çalışanların olumsuz iş davranışları üzerine yapılan incelemeler ve tartışmalar, araştırmacıların dikkatlerini bireysel ve durumsal belirleyiciler üzerinde toplamasina sebep olmuştur (Marcus ve Schuler, 2004). Bu durum, örgütler ve çalışanlar tarafından olumsuz etki ve sonuçlar doğuran (Tepper, 2000) yıkıcı liderliğe ilişkin de incelemelerin başlamasına neden olmuştur (Lu, Ling, Wu ve Liu, 2012).

\section{Yıkıcı Liderlik}

Yıkıcı liderlik kavramına ilişkin çeşitli tanımlamalar yapılmıştır. Ancak yıkıcı liderlik kavramına ilişkin literatürde üzerinde anlaşılmış, kabul görmüş bir tanım bulunmamaktadir. Bu tanımlamalardan bazıları şunlardır: "Kötü niyetli denetçiler" (Tepper, 2000), "sağlığ1 olumsuz etkileyen liderler", "zorbalar", "yoldan sapmış liderler" (Shackleton, 1995), "hoşgörü sahibi olmayan liderler", "psikopatlar", "huzursuz edici ve bıktırıcı liderler". Einersan, Asland ve Skogstad (2007)'a göre yıkıcı liderlik, lider ya da yöneticinin örgütün amaçlarını, hedeflerini, çalışanlarını, yapısını, huzurunu, iş tatminini tehdit eden sistematik ve düzenli olarak tekrar eden davranışları sergilemesidir. Hou (2017) tarafından yıkıcı liderlik, bir örgüt liderinin örgütün içsel ve dişsal paydaşlarına ilişkin olumsuz ve uygun olmayan davranışlar sergilemesi olarak tanımlanmıştır. Vliert ve Einersan (2008)'a göre ise yıkıcı liderlik, liderin kendisini güvence altına almak için çalışanlarının menfaatlerini olumsuz kararlar ve davranışlarla ihlal etmesidir. 
Yıkıcı liderlik kavramına ilişkin yapılan tanımlamalardan da anlaşılacağı üzere yıkıcı liderlik kavramına yönelik olarak liderin olumsuz özelliklerinden bahsedilse de kavramın tanımına ilişkin fikir birliğinden bahsetmek mümkün değildir. Yıkıcı lider; onur kırıcı davranışlarda bulunan, sabotaj, iki yüzlülük, yolsuzluk gibi çeşitli etik olmayan, yasa dışı olarak nitelendirilebilen, suç niteliği taşıyan davranışlar sergileyen lider olarak tanımlanmaktadır. Yıkıcı liderler, örgütün yasal ilgisi dışında yalan konuşma, aldatma, yolsuzluk, hile veya çalarak kendilerini yozlaşma içinde bulabilmektedir. Sonuç olarak yıkıcı liderler izleyenleri kapsadığı gibi örgütü de kapsayan bir kavramdır (Celep, 2014).

Yıkıcı liderlik bazı özellikleri barındırmaktadır. Yıkıcı lider davranışı, astlara ve örgüte yönelik olabilmektedir. Bunun yanında yıkıcı lider davranışı yalnızca örgütün kendisine, yalnızca çalışanlara veya hem örgüte hem de çalışanlara yönelik olumsuz davranışlar içerebilir (Einersan, Asland ve Skogstad, 2010).

Vredenburgh ve Brender (1998)'a göre yöneticiler sahip oldukları güçlerini suistimal ederek ve bu güçlerini kullanarak hem örgüt üyelerini hem de örgütü kötüye kullanma fırsatına sahiptir. Bu yüzden yıkıcı liderler amaçları, görevleri ve kaynakları hedefleyerek örgütün etkililiğinin yanı sira astlarının memnuniyetini, motivasyonunu ve refahını sabote edebilmektedir. Neuman ve Baron (2005)'a göre yıkıcı lider, aslında tüm alanlardan gelen davranış biçimlerini içermektedir. Dolayısıyla yıkıcı liderlik davranışları sadece aktif ve doğrudan davranışları içermekle kalmaz aynı zamanda pasif ve dolaylı davranışları da içermektedir.

Einersan ve diğerlerine (2007) göre yıkıcı liderlik üç temel bileşenden oluşmaktadır. Bunlardan birincisi davranışların sistematik bir şekilde tekrarlanması gerektiğidir. Olumsuz olarak nitelendirilen davranışlar sistematik olarak tekrarlanmıyorsa yıkıcı liderlikten bahsetmek mümkün değildir. İkincisi, yapılan davranışın kasıt içerme durumudur. Liderin ortaya koyduğu davranış, düşüncesizlik, duyarsızlık, yetersizlikten kaynaklanıyor, astları ve/veya örgütü zayıflatıyorsa bu davranış yıkıcı olarak nitelendirilmektedir. Yıkıcı davranışlar lider tarafından ister bilinçli ister bilinçsiz gerçekleştirilsin bu davranışlar tekrarlanıyorsa yıkıcı liderlikten söz etmek mümkündür. Üçüncüsü ise sergilenen davranışlar örgütün meşru yani hukuka uygun ve haklı çıkarlarını ihlal ettiği takdirde yıkıcı olarak nitelendirilebilir. 
Yıkıcı liderlik davranışı sürekli olarak açık bir şekilde saldırganlık veya sözel biçimde olmayabilir. Yıkıcı davranışlar açık olmaktan ziyade kapalı, pasif ve daha gizli olabilir. Yıkıcı lider davranışları bazen olumsuz göz teması, azarlama, bağırma, çok fazla ve katı eleştirilerde bulunma şeklinde olabileceği gibi liderin görevlerini yerine getirmeme, paylaşılması gereken bazı bilgileri gizleme, işgörenlerinin iş güvenliğini sağlayacak faaliyetlerde bulunmama, çalışanları bazı haklarından mahrum bırakma gibi davranışlar şeklinde de ortaya çıkabilmektedir (Einersan vd., 2007).

Yıkıcı liderlik sürecinin ortaya çıkmasında sadece liderin etkisi bulunmamaktadır (Thoroughgood vd., 2011). Yıkıcı lider davranışlarının sergilenmesinde ve bu davranışların devamlı olarak tekrarlanmasında önemli rol oynayan ve bu sürece katkı sağlayan "zehirli" ya da "toksik üçgen" adı verilen üç ana etken bulunmaktadır. Bu üçgenin parçaları lider, izleyenler ve çevredir. Padilla, Hogan ve Kaiser (2007), yıkıcı liderliğin yalnızca lider davranışları ile ilişkili olmadığını, izleyenlerin ve diğer faktörlerin de bu sürece etki ettiğini vurgulamaktadır.

Yıkıcı liderliğin ortaya çıkmasına zemin hazırlayan etmenlerden biri de denetim ve denge unsurudur. Zayıf ve etkisiz olan örgütsel ortam ve kurumsallaşmanın yetersizliği, yıkıcı liderlik davranışının ortaya çıkmasına zemin hazırlamaktadır. Örgütte gücün, merkezi yönetimin elinde bulunması ve gücün merkezileşmesi sonucunda örgüt liderinin denetimi zorlaşmaktadır ve örgütteki güç dengeleri bozulmaktadır (Mulvey ve Padilla, 2010). Devletin denetim mekanizmasının yetersiz olması, devlet kurumlarının iç içe geçmiş yapısı yıkıcı liderlik davranışlarının artmasına sebep olmaktadır (Celep, 2014).

Örgütü amaçlarına ve hedeflerine ulaştırma konusunda problemler yaşayan liderler, örgütsel baskıyı artırarak ve bilerek gerçekleri görmezden gelmek, duygusal bağ kurmaktan kaçınmak, başkalarını kandırmak, sadece kendi yaptıklarını doğru olarak kabul etmek gibi etik dışı davranışlar sergiler. Aynı şekilde aşırı rekabetin var olduğu çevrede yaşayan örgütün liderleri, sahip oldukları yetersiz kaynaklarla büyük amaç ve hedeflere ulaşmaya çalışırken, bu baskı, gerginlik ve tehdit ortamında etik olmayan ve olumsuz davranışlarda bulunabilirler (Chandler ve Fields, 2010).

Yıkıcı liderlik davranışını ortaya çıkaran etkenler bunlarla sınırlı değildir. Liderin örgüt çalışanlarına ulaşılması zor olan, çalışanlarda gerginlik yaratacak ve performanslarının üstünde çaba harcamalarını gerektirecek 
amaçlar belirlemesi ve bunların kısa sure içinde gerçekleşmesini istemesi, liderin örgüt çalışanlarına karşı olumsuz davranışlar sergilemesine neden olmaktadır (Bardes ve Piccolo, 2010).

Örgütün içinde bulunduğu çevrenin karmaşık olması (Celep, 2014), çevrenin değişken yapıda olması kriz durumlarında düzenin sağlanabilmesi için liderin gücünü ve denetimini artırmasına neden olmaktadır. Bu durum yıkıcı liderlik davranışlarını ortaya çıkarmaktadır (Mulvey ve Padilla, 2010).

Yıkıcı liderlik, Uymaz (2013) tarafından altı boyutta ele alınmıştır. Bunlar aşırı otoriterlik, lider için yetkin olmamak, etik dışı davranış, teknoloji ve değişime direnç, astlara karşı duyarsızlık ve adam kayırmadır. "Aşırı otoriterlik", liderin örgüt içinde baskı kurmaya, her şeyi kontrol altında tutmaya çalıştığı, birçok şeye karşı şüpheci olduğu ve örgüt içinde sürekli egemenlik kurma çabasının var olduğu boyuttur. "Liderlik için yetkin olmamak", liderin çalışanların kendilerini geliştirme çabalarını ve onların gereksinimlerini görmezden gelmesi, planlama, vizyon geliştirme, problem çözme ve karar verme becerilerinin zayıf olmasıdır. "Etik dışı davranış", liderin sık sık etik dışı davranışlar sergilemesi, insanlara karşı saygısız olması, dürüstlük gibi erdemlerden uzak olmasını ifade eden yıkıcı liderlik alt boyutudur. "Teknoloji ve değişime direnç", liderin yeni gelişmeleri, teknolojiyi, değişimi, güncel olmayı reddetmesi, var olan düzeni korumak istemesi eğilimidir. "Astlara karşı duyarsızlık", liderin çalışanlarının performansı hakkında çalışanlara geri dönütte bulunmamasıdır. Çalışanlar liderin kendileri hakkında ne düşündüğünü bilmezler. Lider bilgi paylaşımında bulunmaktan kaçınır. "Adam kayırma" ise liderin çalışanlar arasında favori astlarının olması, örgüt içinde belirli kişilere daha ılımlı davranması ve iltimas göstermesidir.

\section{Algılanan Örgütsel Engel}

Örgütler, belirli amaçları ve hedefleri gerçekleştirmek için vardır ve birçok unsurdan meydana gelirler. Örgütlerde liderler, yöneticiler, çalışanlar, normlar, yapılar, stratejiler, hedefler, amaçlar mevcuttur. Bunların hepsi birbiri ile ilişkilidir ve birindeki olumlu veya olumsuz değişim diğerlerini etkilemektedir. Bu etkinin büyüklüğü ve yönü değişiklik gösterebilmektedir. Bu etkileşim içindeki en önemli faktörlerden biri de insan unsudur 
ve insan, doğası gereği gerek birbiriyle gerekse örgütsel yapı ile ilişki içindedir. Bu ilişki bireylerin çeşitli ve kaynağı farklı olan birçok engelle karşılaşmasına neden olmaktadır.

Araştırmacılar tarafından örgüt ve çalışanlar üzerine birçok araştırma yapılmıştır. Örgüt ve çalışan arasındaki ilişki sosyal değişim teorisi temel alınarak açıklanmaya çalışılmıştır (Eisenberger, Fasolo ve Davis-Lamastro, 1990; Graen ve UhlBien,1995; Aktaran: Koçak, 2019). Bu teoriye göre örgüt ve çalışanlar arasında karşılıklı bir beklenti söz konusudur ve bu beklentiler karşılandığı ölçüde süreç devam etmektedir (Emerson, 1976).

Özbağ ve Çekmecelioğlu (2014)'na göre örgütsel engeller, örgütte bulunan çalışanların örgüte ilişkin olumsuz algılamalarıdır. Gibney, Zagenczyk ve Masters (2009) tarafından algılanan örgütsel engel, örgüt tarafından çalışanların amaçlarına ulaşmasınının engellendiği, sınırlandırıldığı ve müdahalede bulunulduğu ve iyi olma haline, huzuruna zarar verildiği şeklindeki algısı olarak tanımlanmıştır. Algılanan örgütsel engel, çalışanların işverenleri ile aralarındaki ilişkinin olumsuz ve zararlı olduğu algısını yansıtmaktadır. Çalışanların bazı konularda örgüt üyeleriyle kişisel sorunlar yaşaması olasıdır. Bu sorunların kaynağı örgütün kendisi değilse çalışanlar bunu örgütsel engel olarak algılamayacaklardır (Gibney, Zagenczyk, Fuller, Hester ve Caner, 2011).

Riege (2005)'ye göre örgütsel engel nedenlerinden bazıları şunlardır: Strateji entegrasyonu, amaçların eksikliği ve belirsizliği, bilgi paylaşım uygulamaları konusunda yönlendirme ve liderlik eksikliği, bilginin yansttılacağı, üretileceği, paylaşılacağ formal ve informal alanların eksikliği, şeffaf bir ödül sisteminin yokluğu, örgüt kültürünün paylaşıma imkan vermemesi, nitelikli ve bilgili personelin ayrıcalıklı olmaması, paylaşımcılığı destekleyen uygun alt yapı eksikliği, örgüt kaynaklarının yetersiz oluşu, alt birimler, iş birimleri veya fonksiyonel alanlarda rekabetin yüksek düzeyde olması, çalışma alanları ve ortamının kısıtlı olması, örgütün hiyerarşik yapıda olması, iletişimi artıracak ve paylaşımı kolaylaştıracak nitelikte küçük iş birimlerinin eksikliği. Northouse (2018) ise yol-amaç liderlik teorisi bağlamında izleyicilerin karşılaşabileceği engelleri yedi başlık altında sıralamıştır. Bunlar; belirsiz amaçlar, belirsiz talimatlar, düşük motivasyon, karmaşık görevler, basit görevler, düşük katılım, rekabet eksikliğidir. 
Gibney ve diğerleri (2009), örgütsel engellerin çalışanların örgütün amaçlarına ulaşması yönünde çabalarını engellediğini ve çalışanın refahına zarar verdiğini öne sürmüştür. Örgütün çalışanları desteklediği yönündeki algı, çalışanlar tarafından artarsa, çalışanların örgütün amaçlarına ulaşmalarına katkı yapmak amacıyla daha fazla gayret gösterdikleri ortaya konmuştur. Çalışanların örgüte katkılarının en az düzeyde sağlandığı durum ise örgütsel desteğin çalışanlara negatif veya nötr olduğu koşullar altındadır. Sosyal değişim teorisi, örgütün çalışanlara sağladığ1 katkı veya verdiği zarar nispetinde çalışanların örgüte katkı veya zarar verebileceğini ileri sürmektedir. Buna göre çalışanların istenmeyen davranışlarının altında yatan sebebin örgütün kendisi olduğu söylenebilir (Eisenberger vd.,1990; Bateman ve Organ, 1983; Gibney vd., 2009).

Sparrowe, Liden, Wayne ve Kraimer (2001) tarafından yapılan araştırmada örgütteki bireylerin görevlerini tamamlamalarını zorlaştıran diğer çalışanları tespit edebildiklerini belirlemişlerdir. Dolayısıyla bireylerin engel olarak algıladıkları şey, göz ardı edilmemekte ve fark edilmektedir. Çalışanların örgütle olan ilişkileri, algılanan örgütsel engelin temelini oluşturmaktadır. Yapılan araştırmalar, çalışanların sürekli olarak bu tür ilişkiler arasında ayrım yaptığını ortaya koymuştur (Brandes, Dharwadkar ve Wheatley, 2004; Cropanzano, Prehar ve Chen, 2002). Ancak, örgütte bireylerin birbirleriyle olan olumsuz ilişkilerinden örgüt sorumlu görülmedikçe, bireylerin örgütsel engel algısı bu olumsuz durumdan etkilenmeyecektir (Gibney ve diğerleri, 2011).

Literatürde algılanan örgütsel engele ilişkin yapılmış sınırlı sayıda araştırma vardır. Bu araştırmaların ortak özelliği algılanan örgütsel engellerin olumsuz yönlerinin açığa çıkarılmış olmasıdır. Yapılan bu araştırmalarda algılanan örgütsel engel ile işte kalma niyeti (Koçak, 2019), algılanan örgütsel destek (Mackey, McAllister, Brees, Huang ve Carson, 2018), adaptif performans (Guillaume, 2012) arasında negatif ilişki olduğu, alg1lanan örgütsel engelin istismarcı yönetim ile astların örgütsel vatandaşlık davranışları arasındaki negatif ilişkide aracı konumda olduğu (Mackey ve diğerleri, 2018), iş güvensizliğinin oluşmasına katkı sağladığı (Lee, 2016) sonucuna ulaşılmıştır. 


\section{Yöntem}

\section{Araştırmanın modeli}

Bu araştırma ilişkisel modelde bir araştırmadır. Creswell (2012)'e göre ilişkisel model, değişkenlerin birbirleriyle olan ilişkilerini belirlememizi ve puanları tahmin etmemizi sağlayan bir araştırma modelidir.

\section{Araştırmanın amacı}

$\mathrm{Bu}$ araştırmanın amacı, öğretmen algılarına göre yıkıcı liderlik ile örgütsel engel arasındaki ilişkiyi incelemektir. Bu amaca yönelik olarak aşağıdaki sorulara cevap aranacaktır.

- Okul yöneticilerinin yıkıcı liderlik davranışı sergileme düzeyi nedir?

- Yıkıcı liderlik davranışlarının sergilenme düzeyi; okul yöneticilerinin cinsiyetine, okulun türüne, okuldaki personel sayısına, öğretmenlerin hizmet yılına göre anlamlı olarak farklılaşmakta mıdir?

- Öğretmenlerin algılarına göre algılanan örgütsel engel düzeyi nedir?

- Algilanan örgütsel engel; okul yöneticilerinin cinsiyetine, okulun türüne, okuldaki personel sayısına, öğretmenlerin hizmet yılına göre anlamlı olarak farklılaşmakta mıdır?

- Yıkıcı liderlik ile algılanan örgütsel engel arasında ilişki var mıdır?

- Yıkıcı liderlik alt boyutları algılanan örgütsel engelleri anlamlı bir şekilde yordamakta mıdır?

\section{Evren ve Örneklem}

Araştırmanın evrenini Sakarya' da görev yapan okul öncesi, ilkokul, ortaokul ve lise öğretmenleri oluşturmaktadır. Evrenden seçkisiz olmayan örnekleme metodlarından uygun örnekleme yöntemi kullanılmıştır. Araştırmanın örneklemini 325 öğretmen oluşturmaktadır. 
Araştırmaya katılan öğretmenlerin 197'si kadın, 128'i erkektir. 64'ü okul öncesi, 83'ü ilkokul, 103'ü ortaokul ve 75'i lisede görev yapmaktadır. 20-30 yaş aralığında 162, 31-35 yaş aralığında 83, 36-40 yaş aralığında 40, 41-45 yaş aralığında 37, 46-50 yaş aralığında 35 öğretmen bulunmaktadır. Öğretmenlerin 147'si 0-5 yıl kıdeme, 75'i 6-10 yıl, 40'1 11-15 yıl, 33'ü 16-20 yıl, 30'u ise 21-25 yıl arasinda kideme sahiptir.

\section{Veri Toplama Araçları}

$\mathrm{Bu}$ araştırmada kullanılan veri toplama araçları şu şekildedir:

Kişisel Bilgi Formu: Katılımcıların demografik bilgilerini (yaş, cinsiyet, çalıştığı okul türü, hizmet yılı) elde etmek için araştırmacı tarafından oluşturulmuştur.

Yıkıcı Liderlik Ölçeği: Bu ölçek Uymaz (2013) tarafından geliştirilmiştir. Ölçek "adam kayırma", "teknoloji ve değişime direnme", "liderlik için yetkin olmama", "etik dışı davranış", "astlara karşı duyarsızlık", "aşırı otoriterlik" boyutlarından ve 28 maddeden oluşan beşli Likert tipinde bir ölçektir. Geliştiren tarafından ölçeğin Cronbach's Alpha değeri 0,966 olarak bulunmuştur. Altı alt boyuttan oluşan ölçeğin toplam varyansın \% 78'ini açıkladığı ölçeği geliştiren araştırmacı tarafından tespit edilmiştir. Algılanan Örgütsel Engel Ölçeği: Bu ölçek, öğretmenlerin algıladıkları örgütsel engel düzeyini belirlemek amaciyla Gibney ve diğerleri (2009) tarafından geliştirilmiş, Koçak (2019) tarafından Türkçe'ye uyarlanmıştır. Geliştiren tarafından ölçeğe ilişkin Cronbach Alpha değeri 0,897 olarak bulunmuştur. Ölçeği geliştiren araştırmacı tarafından ölçeğin yapı geçerliği test edilmiş ve ölçeğin geçerli olduğu belirlenmiştir. Yapılan açımlayıcı faktör analizi sonucunda ölçeğin tek boyutlu yapısı Türkçe uyarlamasinda da desteklenmiştir.

Bu çalışmada kullanılan her iki ölçeğe yönelik Cronbach Alpha değeri 0,97 olarak tespit edilmiştir. Ölçeklerin yüksek derecede güvenilir olduğu bulgulanmıştır.

\section{Verilerin analizi}


Verilerin analizinde frekans, yüzde gibi betimleyici istatistiklerin yanında, iki grubun ortalamalarının karşılaştırılmasında ilişkisiz örneklemler ttesti, ikiden daha fazla grubun ortalamalarının karşılaştırılmasında ise İlişkisiz Örneklem İçin Tek Yönlü Varyans Analizi (ANOVA) yapılmıştır. Korelasyonların belirlenmesinde "Basit Doğrusal Korelasyon" analizi, yordama gücünü test etmede ise "Çoklu Doğrusal Regresyon Analizi" yapılmıştır. Yapılan t-testleri ve ANOVA testleri $\mathrm{p}<.05$ anlamlılık düzeyinde, korelasyon testleri ve regresyon analizi $\mathrm{p}<.01$ anlamlılık düzeyinde çözümlenmiş ve yorumlanmıştır. Verilerin analiz edilmesinde SPSS 22 programı kullanılmıştır.

Araştırmalarda yapılan istatistiksel testlerin, mümkün olduğunca öncelikle parametrik testler kullanılarak yapılması araştırma sonuçlarının güvenirliği ve genellenebilirliği bakımından istenilen bir durumdur (Can, 2014). Bu nedenle araştırmada kullanılan verilerin normal dağılıp dağılmadığı test edilmiştir. Tabachnick ve Fidell (2013)'e göre çarpıklık ve basıklık değerlerinin $+1,5$ ile $-1,5$ arasında yer alması verilerin normal dağıldığının göstergesidir. Bu araştırmada kullanılan verilerin çarpıklık ve basıklık değerleri -0,950 ile 0,956 arasında değişmektedir. Buna göre veriler normal dağılım göstermektedir ve analizlerde parametrik testler kullanılmiştır.

\section{Bulgular}

\section{Birinci Alt Amaca Yönelik Bulgular}

Araştırmanın birinci alt amacı "Okul yöneticilerinin yıkıcı liderlik davranışı sergileme düzeyi nedir?" şeklindedir. Bu amaca ilişkin bulgular Tablo-1'de verilmiştir.

Buna göre okul yöneticilerinin yıkıcı liderlik alt boyutlarından etik dışı davranış ile teknoloji ve değişime direnme davranışlarını sergileme düzeyi çok düşük; aşırı otoriterlik, liderlik için yetkin olmama, astlara karşı duyarsızlık, adam kayırmaya ilişkin davranışları sergilemesi ise düşük seviyededir. En az sergilenen yıkıcı liderlik davranışı teknoloji ve değişime direnme alt boyutuna ilişkin davranışlardır $(\overline{\mathrm{X}}=1,57)$. 
Tablo 1. Okul yöneticilerinin yıkıcı liderlik davranışlarına yönelik öğretmen görüşlerinin aritmetik ortalama $(\bar{X})$ ve standart sapma $(S s)$ değerleri

\begin{tabular}{lccc}
\hline Yıkıcı Liderlik Alt Boyutları & $\boldsymbol{N}$ & $\overline{\mathbf{X}}$ & $\mathbf{S s}$ \\
\hline Aşırı otoriterlik & 325 & 2,05 & 1,01 \\
Liderlik İçin Yetkin Olmamak & 325 & 2,17 & 1,29 \\
Etik Dı̧ıı Davranış & 325 & 1,66 & 0,99 \\
Teknoloji ve Değişime Direnmek & 325 & 1,57 & 0,86 \\
Astlara Karşı Duyarsızlık & 325 & 2,09 & 1,01 \\
Adam Kayırma & 325 & 2,14 & 1,28 \\
\hline Toplam & $\mathbf{3 2 5}$ & $\mathbf{1 , 9 9}$ & $\mathbf{0 , 9 1}$ \\
\hline
\end{tabular}

En fazla sergilenen yıkıcı liderlik davranışı alt boyutu ise liderlik için yetkin olmamaktır $(\overline{\mathrm{X}}=2,17)$. Genel olarak bakıldığı zaman okul yöneticilerinin yıkıcı liderlik davranışlarını sergilemeleri düşük seviyededir $(\overline{\mathrm{X}}=1,99)$.

\section{İkinci Alt Amaca Yönelik Bulgular}

Araştırmanın ikinci alt amacı "Yıkıcı liderlik davranışlarının sergilenme düzeyi okul yöneticilerinin cinsiyetine, okul türüne, okuldaki personel sayısına, öğretmenlerin hizmet yılına göre anlamlı olarak farklılaşmakta mıdır?" şeklindedir. Bu amaçla ilişkisiz örneklemler t-testi yapılmıştır. Tablo-2' de ilişkisiz örneklemler t-testi sonuçları verilmiştir.

Tablo 2. Okul yöneticilerinin cinsiyeti değişkenine göre okul yöneticilerinin yıkıcı liderlik davranışlarına ilişkin öğretmen görüşlerinin aritmetik ortalama $(\bar{X})$, standart sapma (Ss) değerleri ve t-testi sonuçları

\begin{tabular}{lccccccc}
\hline & $\begin{array}{l}\text { Yönetici } \\
\text { Cinsiyeti }\end{array}$ & $\mathbf{N}$ & $\mathbf{X}$ & Ss & sd & t & p \\
\hline Yıkıc Liderlik & Kadın & 65 & 2,00 & 0,65 & 323 & 0,081 & 0,93 \\
& Erkek & 260 & 1,98 & 0,97 & & & \\
\hline $\mathrm{p}<.05$ & & & & & & &
\end{tabular}

İlişkisiz Örneklemler T-testi sonucuna göre okul yöneticilerinin cinsiyetleri ile yıkıcı liderlik davranışları arasında $\mathrm{p}<.05$ düzeyinde anlamlı farklılık bulunmamaktadır $\left(t_{(363)}=0,081, p>05\right)$. 
Tablo 3. Okul türüne göre okul yöneticilerinin yıkıcı liderlik davranışlarına ilişkin öğretmen görüşlerinin anova testi sonuçlarn

\begin{tabular}{lllllll}
\hline & $\begin{array}{l}\text { Varyansların } \\
\text { Kaynağı }\end{array}$ & $\begin{array}{l}\text { Kareler } \\
\text { Toplamı }\end{array}$ & Sd & $\begin{array}{l}\text { Kareler } \\
\text { Ortala- } \\
\text { ması }\end{array}$ & F & p \\
\hline \multirow{2}{*}{ Yıkıcı Liderlik } & Gruplar arası & 2,091 & 3 & 0,697 & 0,824 & 0,482 \\
& Grup İçi & 271,633 & 321 & 0,846 & & \\
\hline p $<.05$ & Toplam & 273,724 & 324 & & & \\
\hline
\end{tabular}

Okul türü ile okul yöneticilerinin yıkıcı liderlik davranışlarına ilişkin öğretmen görüşleri arasında anlamlı farklılık olup olmadığını belirlemek amacıyla yapılan ANOVA testi sonuçlarına göre yıkıcı liderlik ile okul türü arasında anlamlı bir farklılık bulunmamaktadır $\left(F_{(3-321)}=0,824, p>05\right)$.

Tablo 4. Okuldaki personel sayısına göre okul yöneticilerinin yıkıcı liderlik davranışlarna ilişkin öğretmen görü̧slerinin anova testi sonuçlarn

\begin{tabular}{lllllll} 
& $\begin{array}{l}\text { Varyansların } \\
\text { Kaynağı }\end{array}$ & $\begin{array}{l}\text { Kareler } \\
\text { Toplamı }\end{array}$ & Sd & $\begin{array}{l}\text { Kareler } \\
\text { Ortalaması }\end{array}$ & F & p \\
\hline \multirow{3}{*}{ Yıkıcı Liderlik } & Gruplar arası & 20,195 & 3 & 6,732 & 8,523 & 0,000 \\
& Grup İçi & 253,529 & 321 & 0,790 & & \\
& Toplam & 273,724 & 324 & & & \\
\hline p<.05 & & & & & &
\end{tabular}

Okuldaki personel sayısı ile okul yöneticilerinin yıkıcı liderlik davranışlarına ilişkin öğretmen görüşleri arasında anlamlı farklılık olup olmadığını belirlemek amacıyla yapılan ANOVA testi sonuçlarına göre yıkıcı liderlik ile okuldaki personel sayısı arasında anlamlı bir farklılık bulgulanmıştır $\left(\mathrm{F}_{(3-321)}=8,523, \mathrm{p}<.05\right)$. Ortaya çıkan farkın kaynağını belirlemek amacıyla Dunnett's T3 Post Hoc testinden yararlanılmıştır. Test sonucuna göre 1-20 arasında personel bulunan okuldaki yöneticilerin yıkıcı liderlik davranışlarına ilişkin öğretmen görüşleri ortalaması ( $\bar{X}=1,81)$ ile 60 ve üzerinde personeli bulunan okuldaki yöneticilerin yıkıcı liderlik davranışlarına ilişkin öğretmen görüşleri ortalaması $(\bar{X}=2,29)$ arasında istatistiksel olarak anlamlı farklılık bulgulanmıştır $\left(F_{(3-321)}=8,523, p<.05\right)$. 60 ve üzerindepersoneli bulunan okul yöneticilerine ilişkin öğretmen görüşlerinin ortalamaları $(\overline{\mathrm{X}}=2,29), 1-20$ arasında personeli bulunan okul yöneticilerinin yıkıcı liderlik davranışlarına ilişkin öğretmen görüşleri ortalamalarından $(\overline{\mathrm{X}}=1,81)$ daha yüksektir. 
21-40 arasında personeli bulunan okuldaki yöneticilerin yıkıcı liderlik davranışlarına ilişkin öğretmen görüşleri ortalaması $(\bar{X}=2,20)$ ile 41-60 arasinda personeli bulunan okuldaki yöneticilerin yıkıcı liderlik davranışlarına ilişkin öğretmen görüşleri ortalaması $(\bar{X}==1,65)$ arasında istatistiksel olarak anlamlı farklılık bulgulanmıştır $\left(F_{(3-321)}=8,523, \quad p<.05\right)$. 21-40 personeli bulunan okul yöneticilerine ilişkin öğretmen görüşlerinin ortalamaları, 41-60 arasında personeli bulunan okul yöneticilerinin yıkıcı liderlik davranışlarına ilişkin öğretmen görüşleri ortalamalarından daha yüksektir.

41-60 arasında personeli bulunan okuldaki yöneticilerin yıkıcı liderlik davranışlarına ilişkin öğretmen görüşleri ortalaması $(\bar{X}==1,65)$ ile 60 ve üzeri personeli bulunan okuldaki yöneticilerin yıkıcı liderlik davranışlarına ilişkin öğretmen görüşleri ortalaması $(\overline{\mathrm{X}}=2,29)$ arasında istatistiksel olarak anlamlı farklılık bulgulanmıştır $\left(F_{(3-321)}=8,523, \quad p<.05\right) .60$ ve üzeri personeli bulunan okul yöneticilerine ilişkin öğretmen görüşlerinin ortalamaları, 41-60 arasında personeli bulunan okul yöneticilerinin yıkıcı liderlik davranışlarına ilişkin öğretmen görüşleri ortalamalarından daha yüksektir.

Tablo 5. Öğretmenlerin hizmet yılına göre okul yöneticilerinin yıkıcı liderlik davranışlarna ilişkin öğretmen görüşlerinin ANOVA testi sonuçları

\begin{tabular}{lllllll}
\hline & $\begin{array}{l}\text { Varyansların } \\
\text { Kaynağı }\end{array}$ & $\begin{array}{l}\text { Kareler } \\
\text { Toplamı }\end{array}$ & Sd & $\begin{array}{l}\text { Kareler } \\
\text { Ortalaması }\end{array}$ & F & p \\
\hline \multirow{3}{*}{ Yıkıcı Liderlik } & Gruplar arası & 11,624 & 4 & 2,906 & 3,548 & 0,08 \\
& $\begin{array}{l}\text { Grup İçi } \\
\text { Toplam }\end{array}$ & 262,100 & 320 & 0,819 & & \\
\hline
\end{tabular}

$\mathrm{p}<.05$

Analiz sonuçlarına göre yıkıcı liderlik ile öğretmenlerin hizmet yılı arasında anlamlı bir farklılık bulgulanmıştır $\left(F_{(4-32)}=3,548, p<.05\right)$. Ortaya ç1kan farkın kaynağını belirlemek amacıyla Dunnett's T3 Post Hoc testinden yararlanılmıştır.

Test sonuçlarına göre 0-5 yıl arasında hizmeti bulunan öğretmenlerin görüşleri ortalaması $(\overline{\mathrm{X}}=2,00)$ ile 21-25 yıl arasında hizmet süresi bulunan öğretmenlerin görüssleri ortalaması $(\bar{X}=1,21)$ arasında istatistiksel olarak anlamlı farklılık bulgulanmıştır $(F(4-320)=3,548, p<.05)$. 0-5 yıl arasında hizmet süresi bulunan öğretmenlerin görüşleri ortalaması 21-25 yıl arasında 
hizmet süresi bulunan öğretmenlerin görüşleri ortalamasından daha yüksektir.

6-10 yıl arasında hizmeti bulunan öğretmenlerin görüşleri ortalaması $(\bar{X}=1,90)$ ile 21-25 yıl arasında hizmet süresi bulunan öğretmenlerin görüşleri ortalaması $(\overline{\mathrm{X}}=1,21)$ arasında istatistiksel olarak anlamlı farklılık bulgulanmıştır $\left(F_{(4-320)}=3,548, p<.05\right)$. 6-10 yıl arasında hizmet süresi bulunan öğretmenlerin görüşleri ortalaması 21-25 yıl arasında hizmet süresi bulunan öğretmenlerin görüşleri ortalamasından daha yüksektir.

11-15 yıl arasında hizmeti bulunan öğretmenlerin görüşleri ortalaması $(\bar{X}=2,33)$ ile 21-25 yıl arasında hizmet süresi bulunan öğretmenlerin görüşleri ortalaması $(\overline{\mathrm{X}}=1,21)$ arasında istatistiksel olarak anlamlı farklılık bulgulanmıştır $(F(4-320)=3,548, p<.05)$. 11-15 yıl arasında hizmet süresi bulunan öğretmenlerin görüşleri ortalaması 21-25 yıl arasında hizmet süresi bulunan öğretmenlerin görüşleri ortalamasından daha yüksektir.

16-20 yıl arasında hizmeti bulunan öğretmenlerin görüşleri ortalaması $(\bar{X}=2,04)$ ile 21-25 yıl arasında hizmet süresi bulunan öğretmenlerin görüşleri ortalaması $(\overline{\mathrm{X}}=1,21)$ arasında istatistiksel olarak anlamlı farklılık bulgulanmıştır $(F(4-320)=3,548, p<.05)$. 11-15 yıl arasında hizmet süresi bulunan öğretmenlerin görüşleri ortalaması 21-25 yıl arasında hizmet süresi bulunan öğretmenlerin görüşleri ortalamasından daha yüksektir.

\section{Üçüncü Alt Amaca Yönelik Bulgular}

Araştırmanın üçüncü alt amacı “Öğretmenlerin algılarına göre algılanan örgütsel engel düzeyi nedir?" şeklindedir. Bu amaca ilişkin bulgular Tablo-6' da verilmiştir.

Tablo 6. Okul Yöneticilerinin örgütsel engel davranışlarına ilişkin öğretmen görüşlerinin aritmetik ortalama $(\bar{X}=)$ ve standart sapma $(S s)$ değerleri

\begin{tabular}{lccl}
\hline & $\mathbf{N}$ & $\overline{\mathbf{X}}$ & Ss \\
\hline Algilanan Örgütsel Engel & 325 & 1,96 & 1,24 \\
\hline
\end{tabular}

Tablo-6' da görüldüğü gibi öğretmen görüşlerine göre algılanan örgütsel engel düzeyi düşük seviyededir $(X=1,96)$. 


\section{Dördüncü Alt Amaca Yönelik Bulgular}

Araştırmanın dördüncü alt amacı "Algılanan örgütsel engel okul yöneticilerinin cinsiyetine, okul türüne, okuldaki personel sayısına, öğretmenlerin hizmet yılına göre anlamlı olarak farklılaşmakta mıdır?" şeklindedir. $\mathrm{Bu}$ amaca ilişkin bulgular aşağıda verilmiştir.

Tablo 7. Okul yöneticilerinin cinsiyeti değişkenine göre algilanan örgütsel engellere ilişkin öğretmen görüşlerinin aritmetik ortalama $(\bar{X})$, standart sapma (Ss) değerleri ve t-testi sonuçlarn

\begin{tabular}{llllllll}
\hline & Yönetici Cinsiyeti & $\mathbf{N}$ & $\overline{\mathbf{X}}$ & Ss & sd & $\mathbf{t}$ & $\mathbf{p}$ \\
\hline Algılanan Örgütsel Engel & Kadın & 65 & 2,00 & 1,08 & 323 & 0,24 & 0,80 \\
& Erkek & 260 & 1,95 & 1,27 & & & \\
\hline $\mathrm{p}<.05$ & & & & & & &
\end{tabular}

Yapılan analizde öğretmen görüşlerine göre okul yöneticilerinin cinsiyetleri ile algılanan örgütsel engel arasında $p<.05$ düzeyinde anlamlı farklilık bulunamamıştır $\left(t_{(363)}=0,24, p>.05\right)$.

Tablo 8. Okul türüne göre algılanan örgütsel engele ilişkin öğretmen görüşlerinin ANOVA testi sonuçları

\begin{tabular}{lllllll}
\hline & $\begin{array}{l}\text { Varyansların } \\
\text { Kaynağı }\end{array}$ & $\begin{array}{l}\text { Kareler } \\
\text { Toplamı }\end{array}$ & sd & $\begin{array}{l}\text { Kareler } \\
\text { Ortalaması }\end{array}$ & F & P \\
\hline \multirow{3}{*}{ Algılanan Örgütsel Engel } & Gruplar arası & 12,052 & 3 & 4,017 & 2,650 & 0,049 \\
& Grup İçi & 486,656 & 321 & 1,516 & & \\
& Toplam & 498,708 & 324 & & & \\
\hline
\end{tabular}

$\mathrm{p}<.05$

Okul türü ile algılanan örgütsel engel arasındaki ilişkiyi belirlemek amacıyla yapılan ANOVA testi sonuçlarına göre algılanan örgütsel engel ile okul türü değişkeni arasında anlamlı bir farklılık bulgulanmıştır $\left(F_{(3-}\right.$ $321=2,650, p<.05)$. Ortaya çıkan farkın kaynağını belirlemek amacıyla Dunnett's T3 Post Hoc testinden yararlanılmıştır. 
Tablo 9. Öğretmenlerin hizmet süresine göre örgütsel engellere ilişkin öğretmen görüşlerinin ANOVA testi sonuçları

\begin{tabular}{lllllll}
\hline & $\begin{array}{l}\text { Varyansların } \\
\text { Kaynağı }\end{array}$ & $\begin{array}{l}\text { Kareler } \\
\text { Toplamı }\end{array}$ & sd & $\begin{array}{l}\text { Kareler } \\
\text { Ortalaması }\end{array}$ & F & P \\
\hline \multirow{3}{*}{ Algılanan Örgütsel Engel } & Gruplar arası & 3,969 & 4 & 0,992 & 0,652 & 0,633 \\
& Grup İçi & 494,739 & 320 & 1,546 & & \\
& Toplam & 498,708 & 324 & & & \\
\hline $\mathrm{p}<.05$ & & & & &
\end{tabular}

Test sonucuna göre okul öncesi ( $\overline{\mathrm{X}}=2,33)$ ve ilkokul $(\overline{\mathrm{X}}=1,78)$ yöneticileri düzeyinde öğretmenlerin algılanan örgütsel engellere ilişkin görüşlerinin ortalamaları arasında anlamlı farklılık bulgulanmıştır $\left(F_{(3-321)}=2,650\right.$, $p<.05)$. Buna göre okul öncesi yöneticilerine yönelik algılanan örgütsel engel ortalaması, ilkokul yöneticilerine yönelik algılanan örgütsel engel ortalamasından daha yüksektir.

Öğretmenlerin hizmet süresi ile algılanan örgütsel engellere ilişkin öğretmenlerinin görüşleri arasında anlamlı farklılık olup olmadığını belirlemek amaciyla yapılan ANOVA testi sonuçlarına göre algılanan örgütsel engel ile öğretmenlerin hizmet süresi arasında anlamlı bir farklılık bulunamamıştır $\left(F_{(4-320)}=0,652, p>.05\right)$.

Tablo 10. Okuldaki personel sayısına göre algılanan örgütsel engellere ilişkin ANOVA testi sonuçları

\begin{tabular}{|c|c|c|c|c|c|c|}
\hline & $\begin{array}{l}\text { Varyansların } \\
\text { Kaynağı }\end{array}$ & $\begin{array}{l}\text { Kareler } \\
\text { Toplamı }\end{array}$ & sd & $\begin{array}{l}\text { Kareler } \\
\text { Ortalaması }\end{array}$ & $\mathbf{F}$ & $\mathbf{P}$ \\
\hline \multirow{3}{*}{ Algılanan Örgütsel Engel } & Gruplar arası & 13,141 & 3 & 4,380 & 2,896 & 0,035 \\
\hline & Grup İçi & 485,566 & 321 & 1,513 & & \\
\hline & Toplam & 498,708 & 324 & & & \\
\hline
\end{tabular}

Okuldaki personel sayısı ile algılanan örgütsel engel arasında anlamlı farklılık olup olmadığını belirlemek amacıyla yapılan ANOVA testi sonuçlarına göre algılanan örgütsel engel ile okuldaki personel sayısı değişkeni arasında anlamlı bir farklılık bulgulanmıştır $\left(F_{(3-321)}=2,896, p<.05\right)$. Ortaya çıkan farkın kaynağını belirlemek amacıyla LSD Post Hoc testinden yararlanılmıştır.

Test sonuçlarına göre 1-20 arasında personeli bulunan okulda çalışan öğretmenlerin algilanan örgütsel engele ilişkin görüşleri ortalaması $(\bar{X}=1,75)$ ile 21-40 yıl arasında personeli bulunan öğretmenlerin görüşleri 
ortalaması $(\overline{\mathrm{X}}=2,13)$ arasında istatistiksel olarak anlamlı farklılık bulgulanmiştır $(F(3-321)=3,548, p<.05)$. 1-20 arasinda personeli bulunan okulda görev yapan öğretmenlerin algılanan örgütsel engele ilişkin görüşleri ortalaması $(\bar{X}=1,75), 21-40$ yıl arasında personeli bulunan okulda çalışan öğretmenlerin görüşleri ortalamasından $(\overline{\mathrm{X}}=2,13)$ daha yüksektir.

1-20 arasında personeli bulunan okulda çalışan öğretmenlerin algılanan örgütsel engel ortalaması $(\bar{X}=1,75)$ ile 60 ve üzeri personeli bulunan okulda çalışan öğretmenlerin görüşleri ortalaması $(\overline{\mathrm{X}}=2,21)$ arasında da istatistiksel olarak anlamlı farklılık bulgulanmıştır $\left(F_{(3-321)}=3,548, p<.05\right)$. 1-20 arasında personeli bulunan okulda görev yapan öğretmenlerin algılanan örgütsel engel düzeyi $(\bar{X}=1,75), 60$ ve üzeri personeli bulunan okulda çal1şan öğretmenlerin görüşleri ortalamasından $(\bar{X}=2,21)$ daha yüksektir.

\section{Beşinci Alt Amaca Yönelik Bulgular}

Araştırmanın beşinci alt amacı "Yıkıcı liderlik ile algılanan örgütsel engel arasında ilişki var mıdır?" şeklindedir. Yıkıcı liderlik ile örgütsel engel arasındaki ilişkiyi belirlemek amacıyla "Basit Doğrusal Korelasyon" analizi yapılmış ve analiz sonuçları Tablo-11'de verilmiştir.

Tablo 11. Yikıcı liderlik ile örgütsel engel arasındaki ilişki

\begin{tabular}{ll}
\hline Yıkıcı Liderlik Alt Boyutları & Algılanan Örgütsel Engel \\
\hline Aşırı Otoriterlik & $0,63^{* *}$ \\
Liderlik İçin Yetkin Olmamak & $0,72^{* *}$ \\
Etik Dışı Davranı̧̧ & $0,66^{* *}$ \\
Teknoloji ve Değişime Direnmek & $0,51^{* *}$ \\
Astlara Karşı Duyarsızlık & $0,50^{* *}$ \\
Adam Kayırma & $0,70^{* *}$ \\
& Algılanan Örgütsel Engel \\
Yıkıcı Liderlik & $\mathbf{0 , 7 7 ^ { * * }}$ \\
\hline$p<.01$ &
\end{tabular}

Algılanan örgütsel engel ile yıkıcı liderlik alt boyutlarından aşırı otoriterlik, etik dışı davranış, teknoloji ve değişime direnç, astlara karşı duyarsızlık, arasındaki ilişki pozitif orta düzeyde; liderlik için yetkin olmamak, adam kayırma alt boyutları arasındaki ilişki pozitif yüksek düzeydedir. Yıkıcı liderlik ile algılanan örgütsel engel arasında ise pozitif yüksek düzeyde ilişki tespit edilmiştir. 


\section{Altıncı Alt Amaca Yönelik Bulgular}

Araştırmanın altıncı alt amacı "Yıkıcı liderlik alt boyutları algılanan örgütsel engelleri yordamakta mıdır?" şeklindedir. Yıkıcı liderlik alt boyutlarının algılanan örgütsel engelleri ne şekilde yordadığını ortaya koymak amacıyla yapılan Çoklu Doğrusal Regresyon Analizi sonuçları Tablo12 'de verilmiştir.

Tablo 12. Çoklu doğrusal regresyon analizi

\begin{tabular}{|c|c|c|c|c|c|c|c|}
\hline Değişken & B & $\begin{array}{l}\text { Standart } \\
\text { Hata }\end{array}$ & $\beta$ & $t$ & $\mathbf{P}$ & İkili r & K1smi r \\
\hline Sabit & $-0,125$ & 0,100 & & $-1,250$ & 0,212 & & \\
\hline Aşırı otoriterlik & 0,092 & 0,066 & 0,076 & 1,392 & 0,165 & 0,611 & 0,080 \\
\hline $\begin{array}{l}\text { Liderlik İçin Yetkin } \\
\text { Olmamak }\end{array}$ & 0,419 & 0,047 & 0,439 & 8,949 & 0,000 & 0,688 & 0,457 \\
\hline Etik Dışı Davranış & $-0,127$ & 0,103 & $-0,089$ & $-1,239$ & 0,216 & 0,620 & $-0,071$ \\
\hline $\begin{array}{l}\text { Teknoloji ve Deği- } \\
\text { şime Direnmek }\end{array}$ & 0,028 & 0,086 & 0,020 & 0,324 & 0,746 & 0,514 & 0,019 \\
\hline $\begin{array}{l}\text { Astlara Karşı Duyar- } \\
\text { sızlık }\end{array}$ & 0,060 & 0,055 & 0,050 & 1,080 & 0,281 & 0,540 & 0,062 \\
\hline Adam Kayırma & 0,459 & 0,042 & 0,491 & 11,065 & 0,000 & 0,709 & 0,536 \\
\hline $\begin{array}{l}R=0,824 \\
F_{(6-303)}=106,468\end{array}$ & $\begin{array}{l}0,678 \\
000\end{array}$ & & & & & & \\
\hline
\end{tabular}

Yıkıcı liderlik alt boyutlarının algılanan örgütsel engelleri ne şekilde yordadığını ortaya koymak amacıyla yapılan "Çoklu Doğrusal Regresyon Analizi" sonucunda yıkıcı liderlik alt boyutları, algılanan örgütsel engeller ile anlamlı ilişki $\left(R=0,824, R^{2}=0,678\right)$ sergilediği bulgulanmıştır $\left(F_{(6-}\right.$ 303) $=106,468, p<0,01$ ). Söz konusu altı değişken, birlikte, algılanan örgütsel engellerdeki değişimin \%68'ini açıklamaktadır. Standartlaştırılmış regresyon katsayılarına göre yordayıcı değişkenlerin algılanan örgütsel engel üzerindeki göreli önem sırası adam kayırma $(\beta=0,491)$, liderlik için yetkin olmamak $(\beta=0,439)$, aşırı otoriterlik $(\beta=0,076)$, astlara karşı duyarsızlık $(\beta=0,050)$, teknoloji ve değişime direnmek $(\beta=0,020)$, etik dişı davranış $(\beta=-$ $0,089)$ tır. Regresyon katsayılarının anlamlılık testleri göz önüne alınd1ğında yordayıcı değişkenlerden liderlik için yetkin olmamak $(p<0.01)$ ve 
adam kayırma ( $\mathrm{p}<0.01)$ değişkenlerinin algılanan örgütsel engel üzerinde anlamlı yordayıcı olduğu görülmektedir. Yordayıcı değişkenlerle algılanan örgütsel engel arasındaki ilişkilere bakıldığında aşırı otoriterlik ile $(\mathrm{r}=0,611)$, [diğer yordayıcı değişkenlerin etkisi kontrol edildiğinde $(\mathrm{r}=0,080)$ ], liderlik için yetkin olmamak ile $(\mathrm{r}=0,688)$, [diğer yordayıcı değişkenlerin etkisi kontrol edildiğinde $(\mathrm{r}=0,457)$ ], etik dişı davranış ile $(\mathrm{r}=0,620)$, [diğer yordayıcı değişkenlerin etkisi kontrol edildiğinde ( $\mathrm{r}=-$ $0,071)$ ], teknoloji ve değişime direnmek ile $(\mathrm{r}=0,514)$, [diğer yordayıı değişkenlerin etkisi kontrol edildiğinde $(\mathrm{r}=0,019)]$, astlara karşı duyarsızlık ile $(\mathrm{r}=0,540)$, [diğer yordayıcı değişkenlerin etkisi kontrol edildiğinde $(\mathrm{r}=0,062)$ ], adam kayırma ile $(\mathrm{r}=0,709)$, [diğer yordayıcı değişkenlerin etkisi kontrol edildiğinde $(\mathrm{r}=0,536)]$ düzeyinde korelasyon gözlenmektedir.

\section{Tartışma, Sonuç ve Öneriler}

Bilimsel araştırmalarda genel olarak etkili liderlik tipleri üzerinde durulmuştur. Ancak liderliğin karanlık yönü olarak nitelendirilebilecek, bireyleri ve örgütleri olumsuz olarak etkileyen, onlara zarar veren liderlik tipleri üzerinde pek fazla yoğunlaşılmamıştır. Bu liderlik tiplerinden biri de yıkıcı liderliktir. Yıkıcı liderlik bireyleri ve örgütü çeşitli açılardan olumsuz olarak etkileyen, örgütün amaç ve hedeflerini gerçekleştirmesini gerek doğrudan örgüte yönelik davranışlarla gerekse de bireylere yönelik davranışlarla engelleyen, örgüt yapısını ve kültürünü olumsuz olarak etkileyen zarar verici, toksik lider davranışlarıdır. Bu araştırmada yıkıcı liderlik davranışlarının bireylerin örgütsel engel algılamasına etkisi araştırilmıştır.

$\mathrm{Bu}$ araştırmanın sonucuna göre okul yöneticileri yıkıcı liderlik davranışlarını düşük düzeyde sergilemektedir. Sezici (2015), Green (2014) ve Aasland vd. (2010) tarafından yapılan araştırmalarda yıkıcı liderlik davranışlarının sergilenme düzeyinin kısmen yüksek olduğu, ancak Naime ve Naime (2000), Hubert ve Veldhoven (2001) tarafından yapılan araştırmalarda ise yıkıcı ve olumsuz lider davranışlarının sergilenme düzeyinin düşük olduğu sonucuna ulaşılmıştır. Dolayısıyla araştırmanın bu sonucu Naime ve Naime (2000) ile Hubert ve Veldhoven (2001)'ın çalışmalarıyla 
paralellik gösterirken, Sezici (2015), Green (2014) ve Aasland ve diğerleri (2010)'nin çalışmalarıyla zıtlık göstermektedir.

Kadın okul yöneticileri ile erkek okul yöneticilerine ilişkin yıkıcı liderlik davranışları arasında anlamlı farklılık bulunmamaktadır. Hem kadın hem erkek okul yöneticileri, hem de çeşitli okul türlerinde görev yapan okul yöneticileri yıkıcı liderlik davranışlarını düşük düzeyde sergilemektedir. Bu durum yıkıcı liderlik davranışının okullarda hiç sergilenmediği anlamına gelmemektedir. Yıkıcı liderlik davranışlarının okulda az da olsa sergilenmesi öğretmenlerin ve okulun bu davranışlar ile zarar görmesine neden olabilir. Ancak yıkıcı lider davranışlarının sıklığı ve verdiği zararın boyutu arttıkça okula ve okul çalışanlarına olumsuz etkileri de artabilir.

Araştırmanın bir diğer sonucuna göre öğretmenlerin algıladıkları örgüte ilişkin engeller düşük seviyede olduğu gibi kadın okul yöneticileri ile erkek okul yöneticilerine ilişkin öğretmenlerin örgütsel engel algılamaları arasında anlamlı farklılık bulunamamıştır. Ayrıca hem kadın hem erkek okul yöneticilerine ilişkin öğretmenlerin örgütsel engel algılamaları düşük seviyededir. Okul yöneticilerine ilişkin öğretmenlerin örgütsel engelleri algılama düzeylerinin düşük olması öğretmenlerin çoğunun kendilerini geliştirmelerine daha fazla imkan tanındığını, koyduğu bireysel veya mesleki hedeflere ulaşmak için öğretmenlerin daha az engellendiğini göstermektedir.

Yıkıcı lider davranışlarının oluşmasında izleyenler de etkili bir unsurdur (Einersan, 2007). Örgütleri oluşturan unsurlardan biri de insanlar olduğuna göre liderlerin örgüt üyeleriyle etkileşimde bulunması kaçınılmaz bir durumdur. Örgüt üyelerinin kendisinden kaynaklanan nedenlerden dolayı okul yöneticileri, bazen yıkıcı lider davranışlarını sergileyebilmektedir. Bu araştırmada genel olarak okuldaki personel sayısı arttıkça okul yöneticilerinin yıkıcı lider davranışlarına ilişkin öğretmen algılamalarında da artış görülmüştür. Okullarda öğretmen sayısının fazla olması farklı kişilik özelliklerine, farklı düşünce yapılarına sahip öğretmenlerin bir arada bulunmasını ifade eder. Okul yöneticisi bu farklılıklarla etkileşimde bulunmak zorundadır. Öğretmen sayısı fazla olan okullarda okul yöneticileri daha fazla bireysel farklılıklara maruz kalmakta ve öğretmenlerin bireysel istekleri, narsizm, karşılanamayan istekleri gibi çeşitli sebeplerden dolayı okul yöneticileri yıkıcı lider davranışını sergileyebilmekte veya okul yöneticilerinin sergilediği davranışlar tüm bu farklılıklara hitap 
edememekte ve liderin davranışları öğretmenler tarafından yıkıcı olarak algilanmaktadır.

Öğretmenlerin okul yöneticilerinin yıkıcı liderlik davranışlarına ilişkin algıları öğretmenlerin hizmet sürelerine göre değişim gösterdiği bulgulanmıştır. Araştırmaya katılan öğretmenlerden hizmet süresi en fazla olanların okul yöneticilerine ilişkin yıkıcı liderlik algısı ile daha az hizmet süresine sahip olan öğretmenlerin okul yöneticilerine ilişkin yıkıcı liderlik algısı arasında anlamlı farklılıklar bulunmaktadır. Daha deneyimli öğretmenlerin okul yöneticilerinin yıkıcı liderlik davranışlarına ilişkin algılamaları diğerlerine oranla daha düşüktür. Araştırmanın bu bulgusu Sezici (2015)'in araştırma bulgusuyla paralellik göstermektedir. Daha tecrübeli öğretmenlerin farklı bölgelerde farklı öğretmenlerle ve okul yöneticileriyle çalıştığı düşünülürse, bu öğretmenlerin okul yöneticilerinin yıkıcı liderlik davranışlarına daha toleranslı olduğu ve bu davranışlara maruz kalma algılamalarının daha düşük olduğu belirtilebilir. Öğretmenlerin deneyimleri arttıkça ve farklı okul kültürlerinde, çeşitli sosyo-ekonomik ve farklı kültürden bireylerle ve okul yöneticileriyle etkileşimde bulunma olanağı arttıkça, yıkıcı liderlik davranışlarına maruz kalma durumu da zamanla artmaktadır. Ancak bu davranışların deneyimli öğretmenlere yansıması ve onları olumsuz etkileme düzeyi azalmaktadır. Hizmet süresi artan öğretmenin mesleki ve kişisel deneyimi de artmakta ve diğerlerine yıkıcı gelen lider davranışları onlar tarafından yıkıcı olarak algılanmayabilmektedir. Ancak öğretmenlerin algıladıkları örgütsel engellere ilişkin böyle bir durum söz konusu değildir. Öğretmenlerin deneyimi ne olursa olsun örgütsel engellerle karşılaştıklarında bu engellere ilişkin algıları anlamlı olarak farklılaşmamaktadır. Örgütsel engeller hem daha az deneyimli öğretmenler hem de daha deneyimli öğretmenler tarafından yakın seviyede algılanmaktadır. Bu noktada deneyimli öğretmenlerin karşılaştıkları örgütsel engellere ilişkin toleranslarından bahsedilemez. Dolayısıyla öğretmenler kendi gelişimlerine, amaç ve hedeflerine ulaşma isteklerini engelleyecek davranışları mesleklerinin hiçbir safhasında görmezden gelememekte, bu duruma duyarsız kalamamaktadır. Araştırmanın bu sonucu Sparrowe ve diğerlerinin (2001) araştırmasıyla paralellik göstermektedir.

Araştırmanın bir diğer sonucuna göre okulda çalışan personel sayısı arttıkça öğretmenlerin örgütsel engelleri algılama düzeyi artmaktadır. 
Okulda görev yapan personel sayısının fazla olması okul yöneticilerinin daha fazla bireyle ilişki içerisinde olmasına, çatışma ortamına daha fazla maruz kalmasına, istek ve gereksinimlerin çoğalmasına neden olmaktadır. Örgütteki üye sayısının daha fazla olması, bireylerin birbirleriyle iletişimi ve çatışma yaşanma ihtimalini artırmaktadır. Kısacası örgütte çalışan sayısının fazla olması, liderlerin işini daha da zorlaştırmaktadır. Okul kurallarına uyma konusunda problemler yaşanabilmekte, istek ve ihtiyaçların sınırlı kaynaklarla karşılanması çeşitli sorunlara yol açabilmekte, eğitim ve öğretime ilişkin faaliyetlerde, planlamalarda ve uygulamalarda problemler görülmektedir. Bu durum öğretmenlerin örgütsel engellere ilişkin algı seviyelerinin artmasına neden olabilir.

Araştırmada yıkıcı liderlik alt boyutlarından liderlik için yetkin olmamak ve adam kayırma alt boyutlarının algılanan örgütsel engelleri anlamlı olarak yordadığıbulgulanmıştır. Riege (2005)'ye göre bireylerin algıladıkları örgütsel engellerin sebeplerinden biri de liderlik eksikliğidir. Dolayısıyla öğretmenlerin örgütsel engellerle karşılaşmalarından biri de okul yöneticilerinin etkili liderlik davranışlarını sergilememesidir. Okul yöneticileri sadece yönetici olmaktan ziyade değişen durumlar çerçevesinde belli başlı lider özelliklerini de sergileme kabiliyetine sahip olmalıdır. Bursalıoğlu (2013)'na göre okul yöneticisi örgütün amaçları ile üyelerinin ihtiyaçlarını bir bütün olarak görüp birisi üzerinde durmamalıdır. Okul yöneticisi bu iki boyut arasında değişen durumlara göre bir tutum sergilemelidir.

Okul yöneticilerinin okul içerisinde belli başlı bireylere iltimas göstermesi okul içerisinde farklı standartların oluşmasına ve bu durum da öğretmenlerin okul yöneticisine ilişkin tutumlarında değişmeye, öğretmenleri kişisel ve mesleki olarak olumsuz etkileyebilir. Okulda belirli bir kişilere veya gruplara gösterilen iltimas, kişilerin bireysel ve mesleki amaç ve hedeflerini gerçekleştirmelerine ilişkin de olabilmektedir. Bu durumda bireyler bu davranışları örgütsel engel olarak algılayabilir, örgüt ve örgüt üyeleri bu durumdan olumsuz olarak etkilenebilir.

Örgüt üyelerinin örgütsel engellere maruz kalmalarına sebep olan birçok etken bulunmaktadır. Bunlardan biri de örgüt liderlerinin yıkıcı davranışlarıdır. Bu araştırmanın sonucuna göre yıkıcı liderlik ile algılanan engeller arasında yüksek düzeyde pozitif ilişki bulgulanmıştır. Vahdati, Saedi ve Moumeni (2020) tarafından yapılan araştırmada toksik liderlik ile 
örgütsel engel arasında pozitif ilişki tespit edilmiş ve toksik liderliğin örgütün insan kaynakları devir hızı üzerindeki etkisinde örgütsel engelin aracı rolü olduğu sonucuna ulaşılmıştır. Dolayısıyla araştırmanın bu sonucu Vahdati, Saedi ve Moumeni (2020)'nin araştırmasıyla paralellik göstermektedir. Literatürde yıkıcı liderlik ile örgütsel engel arasındaki ilişkiyi inceleyen herhangi bir çalışma bulunmamaktadır. Ancak yıkıcı liderlik ile ilgili yapılan bazı çalışmalarda çalışanların örgütsel engel algılamaları ile doğrudan veya dolaylı olarak ilişki içinde olduğu düşünülen faktörler ele alınmıştır. Yıkıcı liderlik veya toksik liderlik ile ilgili yapılan çalışmalarda yıkıcı liderliğin örgüt sağlığını olumsuz yönde etkilediği (Reyhanoğlu ve Akın, 2016); bireylerin işten ayrılmalarını artırdığı (Raaj ve Gunaseelan, 2016; Shaw, Erickson ve Harvey, 2011; Tate, 2009); çalışanların memnuniyetini, iş tatminini azalttı̆g 1 (Tra, Tian ve Sankoh, 2013; Reed ve Bullis, 2009; Rayner ve Cooper, 1997); yıkıcı liderlik ile lidere yönelik olumsuz tutum, bireysel refah ve bireysel performans arasında negatif ilişki olduğu; işten ayrılma niyeti, lidere karşı direnç, üretken olmayan çalışma davranışı arasında pozitif ilişki olduğu (Schyns ve Schilling, 2013); yıkıcı liderlik davranışlarının iş doyumunu nötrleştirdiği (Schaubroeck, Walumbwa, Ganster ve Kepes, 2007); örgütsel performansı olumsuz etkilediği (Ashforth, 1997); çalışanların verimsiz iş davranışlarına neden olduğu (Duffy, Ganster, Pagon, 2002); motivasyon eksikliğini artırdı̆̆ 1 (Chan, Lam, Chow ve Cheung, 2008); örgütsel bağlılığ1 (Rayner ve Cooper, 1997), bireysel özyeterliği ve özgüveni azattığı (Einersan, 1999; Einersan ve Raknes, 1997) sonuçlarına ulaşılmıştır. Bu çalışmada yıkıcı liderlik ile olumsuz bir durum olarak görülen algılanan örgütsel engel arasında pozitif ve yüksek bir ilişki ortaya çıkmıştır. Yapılan araştırmalardaki değişkenler, aynı zamanda çalışanların örgütsel engel algılamaları ile de doğrudan veya dolaylı olarak ilişkilidir. Dolayısıyla yukarıda bahsedilen araştırmalar, araştırmanın bu sonucu ile paralellik göstermektedir.

Araştırmanın sonucuna göre bir lider ne kadar yıkıcı davranışlar sergiliyorsa örgüt üyelerinin algıladıkları örgütsel engel o kadar fazla olmaktadır. Toplumların ve ülkelerin gelişmelerinde ve hayatta kalabilmelerinde en önemli yapı taşlarından biri olan eğitim kurumlarında okul yöneticilerinin yıkıcı liderlik davranışları sergilemeleri öğretmenlerin ve dolayısıyla öğrencilerin, velilerin, okul çevresinin ve kültürünün okula ilişkin olumlu algılarının azalmasına, bu nedenle de öğretmenlerin amaç ve 
hedeflerini gerçekleştiremediği gibi okulun da nihai amaç ve hedeflerini sağlıklı bir şekilde gerçekleştirememelerine neden olmaktadır. Bu durum özelde okulun tüm unsurlarını genelde toplumu etkileyebilir.

Yıkıcı liderliğin hem astlara hem de örgüte yönelik olumsuz etkileri birçok çalışmada ortaya çıktığı düşünüldügünde yıkıcı liderlik çalışma hayatında ciddi bir sorun oluşturmaktadır. Bir örgütün başarısı lider davranışlarının etkililiğine bağlıdır. Lider, etkili özelliklerine sahipse ve buna rağmen olumsuz liderlik davranışları sergilerse bu durum yalnızca astlarının değil örgütün de bundan olumsuz etkilenmesine yol açabilir (Yen, Tian ve Sankoh, 2013). Örgütün amaç ve hedeflerini yerine getirebilmeleri ve varlığını sürdürebilmelerinin koşullarından birisi de etkili, örgüt üyelerini örgütün amaçları ve hedefleri doğrultusunda harekete geçirebilen, motive edebilen, onları örgütün amaçları doğrultusunda yönlendirebilen etkili liderlere sahip olmasıdır. Örgütlerde etkili bir liderin eksikliği, örgütü ve örgüt üyelerini doğrudan veya dolaylı olarak olumsuz yönde etkilemektedir. Okul yöneticilerinin olumlu bir okul iklimi yaratabilmesi, onların etkili liderler olabilmesine bağlı olabilir. Yıkıcı davranışlarda bulunan okul yöneticileri öğretmenlere, okul kültürüne ve iklimine ciddi zararlar verebilir. Öğretmenlerin okula ilişkin olumsuz algıları etkili bir eğitim-öğretim ortamının oluşmasını engeller. Eğitimin amaçlarına ulaşabilmesi öğretmenlerin okulu benimsemeleri ve okula ilişkin olumlu tutum sergileyerek motivasyonunu ve enerjisini eğitimin amaçları doğrultusunda yönlendirmesine bağlıdır. Bu nedenle okul yöneticileri yıkıcı lider davranışlarından uzak durarak bu ortama zemin hazırlamamalı, yönetici olmanın yanında bir lider olarak eğitimin amaçlarına ulaşabilmesi için en etkili lider davranışlarını bu doğrultuda sergilemelidir.

Yıkıcı liderliğin sadece örgüt üyelerinin örgütsel engellere ilişkin alg1larının dışında diğer konularda da çalışılması gerekmektedir. Yıkıcı liderliğe ilişkin yapılan çalışmalar genel olarak yıkıcı liderliğin bireylere ilişkin etkileri üzerine yoğunlaşmış durumdadır. Yıkıcı liderliğin bireylere yönelik diğer çalışma alanları yanında örgüte yönelik etkilerinin de araştırılması yararlı olacaktır. 


\title{
EXTENDED ABSTRACT
}

\section{Analysis of the Relationship Between the Destructive Leadership and the Perceived Organizational Obstacles}

\author{
Münevver Çetin- Muammer Maral \\ Marmara Üniversitesi
}

People tend to live together because of their social being and the advantages it provides. The coexistence of people has led to the emergence of various groups and communities. Leadership arose out of the need to manage these groups and communities. This situation is a natural consequence of both the need to manage groups and communities and the need to be managed groups and communities (Erkutlu, 2014).

Leadership has been the subject of social sciences such as psychology, history, political science, sociology, and management science (Çelik, 2015; Hughes, Ginnett and Gordon, 1999). More than 3000 empirical studies have been conducted on leadership, and over hundreds of thousands of studies have been conducted (Barutçugil, 2014; Çelik, 2015). Today, there are many definitions, theories and approaches regarding leadership (Barutçugil, 2014). Although the concept of leadership has been given many meanings in every field with a management function from past to present, the concept of leadership has always existed and has not lost its importance (Çelik, 2015).

Leader and leadership have been a debated issue from past to present (Barutçugil, 2014). However, the first serious studies started in the 20th century. Many of the leadership researches are on the factors that affect the effectiveness of leaders. Social scientists have tried to determine how a leader influences his followers, their level of influence, how and to what extent they perform their duties and the characteristics, behaviors, power sources and abilities that enable them to achieve all of these, why some leaders come to the fore in organizations and the factors that determine the leader's behavior (Yukl, 2018). Since the first serious studies that started with the "Traits Theory" at the end of the 1930s, positive characteristics of leaders have been emphasized, and destructive leadership, which 
is the "dark side" of leadership, has not been sufficiently focused (Celep, 2014). The number of studies on the harmful and negative effects of destructive leadership in organizations and the theory developed for this are very few (Tepper, 2000). Most of the researches are about constructive, successful and effective leadership (Kelloway, Mullen ve Francis, 2006). Traditionally, research on leadership has been on the factors of effective leadership, and often the assumption is that ineffective leadership simply reflects the "absence of leadership" (Asforth, 1994).

Destructive leadership refers to the systematic and repetitive harmful leader behaviors that are performed intentionally or unintentionally, towards employees and the organization. According to the researches, employees exhibit discouragement from their jobs, employees are exposed to intolerant employers (Lombardo and Mc Call, 1984; Zapf, Einersan, Hoel, and Vartia, 2003) destructive leadership negatively affects the job satisfaction levels of the employees and causes them to exhibit the behavior of disrupting their jobs, it reduces the organizational commitment level of the employees, increases the tendency of employees to leave their jobs (Sezici, 2015), causes the misuse of resources (Çetin, 2019). All these studies reveal that leaders actively display destructive behaviors in addition to the mentioned positive behaviors.

In this study, the relationship between destructive leadership and organizational obstacles will be examined. It will be tried to determine the relationship of destructive leadership behaviors with organizational barriers that prevent individuals' professional and personal development, reduce their welfare and job performance, negatively affect their success and motivation, and cause many other negative situations such as increased stress levels. It will be questioned whether the employees are exposed to destructive leadership behaviors, if so, what their level is, and whether these behaviors cause members of the organization to encounter organizational obstacles, and if so, to what extent.

This research was designed correlational model. The correlational model is a research model that allows us to determine the relationships of the variables with each other and to predict the scores (Creswell, 2012). The aim of this study is to examine the relationship between destructive leadership and organizational barrier according to teachers' perceptions. 
Preschool, primary, secondary and high school teachers working in Sakarya constitute the universe of the research. One of the non-random sampling methods from the universe, convenience sampling was used. The sample of the study consists of 325 teachers. In data collection, "Personal Information Form" developed by the researcher, "Destructive Leadership Scale" developed by Uymaz (2013), "Perceived Organizational Obstacle Scale" developed by Gibney et al. (2009) and adapted to Turkish by Koçak (2019) were used. Cronbach's Alpha value of the Destructive Leadership Scale is 0.966 . It has been determined that the scale consisting of six subdimensions explains $78 \%$ of the total variance. The Cronbach Alpha value calculated for the "Perceived Organizational Barrier Scale" was found to be 0.897 . The Cronbach Alpha value for both scales used in this study was determined as 0.97 . The scales were found to be highly reliable.

In the analysis of the data, besides descriptive statistics such as frequency and percentage, independent samples t-test was used to compare the means of two groups, and one-way analysis of variance (ANOVA) was used to compare the means of more than two groups. "Simple Linear Correlation" analysis was used to determine the correlations, and "Multiple Linear Regression Analysis" was used to test the predictive power. T-tests and ANOVA tests were analyzed and interpreted at $\mathrm{p}<.05$ significance level, correlation tests and regression analysis at $\mathrm{p}<.01$ significance level. SPSS 22 program was used to analyze the data.

Performing statistical tests in studies using parametric tests as much as possible is desirable in terms of reliability and generalizability of research results (Can, 2014). For this reason, it was tested whether the data used in this study were normally distributed. According to Tabachnick and Fidell (2013), the skewness and kurtosis values being between $+1,5$ and $-1,5$ indicates that the data are distributed normally. The skewness and kurtosis values of the data range between -0.950 and 0.956 . Accordingly, the data show a normal distribution. Therefore, parametric tests were used in statistical analysis.

In the research findings, it was determined that the level of performing destructive leadership of school administrators was low and significant difference was found between the destructive leadership and the number of school staff and tenure of teachers. According to the teachers' perceptions, the level of perceived organizational obstacle was determined to be 
low, and there was a significant difference between the perceived organizational obstacle and the type of school and the number of staff at school. It was determined that the dimensions of "inadequate leadership skills" and "nepotism (favoritism)" which are destructive leadership sub-dimensions, significantly predict the perceived organizational obstacles, and a high level of positive relationship was found between destructive leadership and perceived organizational obstacle.

\section{Kaynakça / References}

Ashforth, B. E. (1997). Petty tyranny in organizations: A preliminary examination of antecedents and consequences. Canadian Journal of Administrative Sciences, 14 (2), 126-140.

Bardes, M. ve Piccolo, R. F. (2010). Goal setting as an antecedent of destructive leader behaviors: When leadership goes wrong: destructive leadership, mistakes, and ethical failures. Greenwich: Information Age Publishing.

Barutçugil, İ. (2014). Liderlik. İstanbul: KariyerYayınları.

Bateman, T. S. ve Organ, D. W. (1983). Job satisfaction and the good soldier: The relationship between affect and employee citizenship. Academy of Management Journal, 26 (4), 587-595.

Brandes, P., Dharwadkar, R., and Dean, J. W. (1999, Mayıs). Does organizational cynicism matter? Employee and supervisor perspectives on work outcomes. Eastern Academy of Management Proceedings, 2, 150-153.

Bursalığlu, Z. (2013). Okul yönetiminde yeni yapı ve davranış. Ankara: Pegem Akademi.

Can, A. (2014). SPSS ile bilimsel araştırma sürecinde nicel very analizi. Ankara: Pegem Akademi.

Celep, C. (2014). Eğitim yöneticisinin liderlik davranışı. Ankara: Nobel AkademikYayıncilik.

Chan, D. K., Chow, S. Y., Lam, C. B. ve Cheung, S. F. (2008). Examining the job-related, psychological, and physical outcomes of workplace sexual harassment: A meta-analytic review. Psychology of Women Quarterly, 32 (4), 362-376. 
Chandler, D. J. ve Fields, D. (2010). Ignoring the signposts: A process perspective of unethical and destructive leadership. B. Schyns and T. Hansbrough (Der.), When leadership goes wrong: Destructive leadership, mistakes, and ethical failures (s.99-143). USA: IAP Information Age Publishing.

Christie, R. ve Geiss, F. L. (1970). Studies in machiavellianism. New York: Academic Press. 14 Kasım 2019 tarihinde, https://www.amazon.com/Studies-Machiavellianism-Social-Psychology-Monographsebook/dp/B01M1BFIW2 adresindenerişildi.

Creswell, J. W. (2012). Educational research: Planning, conducting, and evaluating quantitative. Boston: Pearson.

Cropanzano, R., Prehar, C. A., and Chen, P. Y. (2002). Using social exchange theory to distinguish procedural from interactional. Group and OrganizationManagement, 27, 324-351.

Çelik, V. (2015). Eğitimselliderlik. Ankara: PegemAkademi.

Çetin, I. (2019). Yıkıcı liderlerde etik dışı davranışlar. Balkan ve Yakın Doğu BilimlerDergisi, 5 (2), 108-119.

DuBrin, A. J. (1995). Leadership research findings, practice, and skills. Boston: Houghton Mifflin.

Duffy, M. K., Ganster, D. C. vePagon, M. (2002). Social undermining in the workplace. Academy of Management Journal, 45 (2), 331-351.

Einarsen, S. (1999). The nature and causes of bullying at work. International journal of manpower. 20 (1/2). 16-27.

Einarsen, S. veRaknes, B. I. (1997). Harassment in the workplace and the victimization of men. Violence and victims, 12 (3), 247-263.

Einersan, S., Asland, M. S. veSkogstad, A. (2007). Destructive leadership behaviour: a definition and conceptual model. The Leadership Quarterly, 18 (3), 207-216.

Einersan, S., Asland, M. S. veSkogstad, A. (2010). The nature, prevelance and outcomes of destructive leadership: A behavioral and conglomerate approach.B. Schyns, and T. Hansbrough (Der.), When leadership goes wrong: Destructive leadership, mistakes, and ethical failures içinde (145171). Charlotte: IAP Information Age Publishing.

Eisenberger, R., Fasolo, P. ve Davis-Lamastro, V. (1990). Perceived organizational support and employee diligence, commitment, and innovation. Journal of Applied Psychology, 75(1), 51-59. 
Emerson, R. M. (1976). Social exchange theory. Annual Review of Sociology, 2(1), 335-362.

Erkutlu, H. V. (2014). Liderlik, kuramlarve yeni bakışaçıları. Ankara: Efi1Yayınevi.

Gibney, R., Zagenczyk, T. J. ve Masters, M. F. (2009). The negative aspects of social exchange: An introduction to perceived organizational support. Group and Organization Management, 34(6), 665-697.

Gibney, R., Zagenczyk, T. J., Fuller, J. B., Hester, K. ve Caner, T. (2011). Exploring organizational obstruction and the expanded model of organizational identification. Journal of Applied Social Psychology, 41(5), 1083-1109.

Green, J. E. (2014). Toxic Leadership in Educational Organizations. Education Leadership Review, 15(1), 18-33.

Guillaume, R., Bazine, N., Fréour, L., Peña-Jimenez, M., Cangialosi, N., Battistelli, A. (2021). From feedback seeking to psychological attachment, the mediating role of adaptive performance in perceived obstruction context. The Spanish Journal of Psychology, 24, 1-18. https://doi.org/10.1017/SJP.2021.1

Gündüz, Y. veDedekorkut, S. E. (2014). Yıkıcı liderlik. Mersin Üniversitesi Eğitim Fakültesi Dergisi, 10(1), 95-104.

Hou, X. (2017). Multilevel influence of destructive leadership on millennial generation employees' innovative behavior. Social Behavior and Personality: An International Journal, 45(7), 1113-1126.

Hubert, A. B. ve Van Veldhoven, M. (2001). Risk sectors for undesirable behaviour and mobbing. European Journal of Work and Organizational Psychology, 10(4), 415-424.

Hughes, R. L., Ginnett, R. C. ve Gordon, C. J. (1999). Leadership: Enhancing the lessons of experience. Irwin: McGraw Hill.

Kellerman, B. (2004). Bad leadership: What it is, how it happens, why it matters. Boston: Massachusetts: Harvard Business School Press.

Kelloway, E. K., Mullen, J. ve Francis, L. (2006). Divergent effects of transformational and passive leadership on employee safety. Journal of Occupational Health Psychology, 11(1), 76-86.

Koçak, D. (2019). Algılanan örgütsel engel ölçeğinin Türkçe uyarlaması ve işte kalma niyeti üzerindeki etkisi. Business and Management Studies: An International Journal, 7(1), 58-77.

Koçel, T. (2010). İşletme yöneticiliği. İstanbul: Beta Yayınları. 
Lee, E. R. (2016). The research about mediating effect of perceived organizational obstruction in the relationship with job insecurity and EVLN. Journal of Digital Convergence, 14(2), 99-114.

Lombardo, M. M. ve McCall, M. W. (1984). Coping with an intolerable boss. Greensboro: Center for Creative Leadership. 24 Aralık 2019 tarihinde, https://books.google.com.tr/books/about/Coping_with_an_Intolerable_Boss.html?id=443ZAAAAMAAJ\&redir_esc=y adresindenerişildi.

Lu, H., Ling, W., Wu, Y. ve Liu, Y. (2012). A Chinese perspective on the content and structure of descruptive leadership. Chinese Management Studies, 6(2), 271-283.

Mackey, J. D., McAllister, C. P., Brees, J. R., Huang, L. andCarson, J. E. (2018). Perceived organizational obstruction: A mediator that addresses sourcetarget misalignment between abusive supervision and OCBs. Journal of Organizational Behavior, 39(10), 1283-1295.

Marcus, B. ve Schuler, H. (2004). Antecedents of counterproductive behavior at work: A general perspective. Journal of Applied Psychology, 89(4), 647-660.

Mulvey, P. ve Padilla, A. (2010). The environment of destructive leadership. S. Birgit, and H. Tiffany (Der). When leadership goes wrong: Destructive leadership, mistakes and ethical failures içinde (s.49-71). Charlotte: Information Age Publishing.

Namie, G. ve Namie, R. (2009). Bully at work: What you can do to stop the hurt and reclaim your dignity on the job. Sourcebooks, Inc: Naperville.

Neuman, J. H. ve Baron, R. M. (2005). Aggression in the workplace: A socialpsychological perspective. S. Fox, and P. E. Spector (Der.), Counterproductive work behavior: Investigations of actors and targets içinde (s.13-40). Washington, DC: American Psychological Association.

Northouse, P. G. (2018). Introduction to leadership: Concept and practice. London: SAGE Publications.

Özbağ, G. ve Çekmecelioğlu, H. (2014). Örgütsel engeller, psikolojik güçlendirme ve yaratıcı davranış arasındaki ilişkilerin kobi çalışanları üzerinde incelenmesi. 22. Ulusal Yönetim ve Organizasyon Kongresi. Konya: Selçuk Üniversitesi İktisadi ve İdariBilimler Fakültesi.

Padilla, A., Hogan, R. ve Kaiser, R. B. (2007). The toxic triangle: Destructive leaders, susceptible followers, and conducive environments. The Leadership Quarterly, 18(3), 176-194. 
Raaj, V.G. veGunaseelan, R. (2016). Destructive leadership and subordinates intention to leave: An empirical study. Indian Journal of Research, 5 (4), 77-79.

Rayner, C. ve Cooper, C. (1997). Workplace bullying: myth or reality-can we afford to ignore it?. Leadership and Organization Development Journal. 18(4), 211-214.

Reed, G. E. veBullis, R. C. (2009). The impact of destructive leadership on senior military officers and civilian employees. Armed Forces and Society, 36(1), 5-18.

Reyhanoğlu, M. veAkın, Ö.(2016). Toksik liderlik örgütsel sağlığı olumsuz yönde tetikler mi?. Insan ve Toplum Bilimleri Araştırmaları Dergisi, 5(3), $442-459$.

Riege, A. (2005). Three-dozen knowledge-sharing barriers managers must conside. Journal of Knowledge Management, 9(3), 18-35.

Sezici, E. (2015). İzleyicilerinyıkıcıliderlikalgısıvesonuçları. 23. Ulusal Yönetim ve Organizasyon Kongresi. 2.Muğla: Muğla Sıtkı Koçman Üniversitesi Yayınları.

Shackleton, V. (1995). Business leadership. London: Routledge Inc. 29 Aralık 2019 tarihinde, https://www.abebooks.co.uk/book-search/title/business-leadership/author/shackleton/ adresindenerişildi.

Schaubroeck, J., Walumbwa, F. O., Ganster, D. C. veKepes, S. (2007). Destructive leader traits and the neutralizing influence of an "enriched" job. The Leadership Quarterly, 1(3), 236-251.

Schyns, B. ve Schilling, J. (2013). How bad are the effects of bad leaders? A meta-analysis of destructive leadership and its outcomes. The Leadership Quarterly, 24(1), 138-158.

Tabachnick, B. G., \& Fidell, L. S. (2013). Using multivariate statistics. Boston: Pearson.

Tate, B. W. (2009). Bad to the bone: Empirically defining and measuring negative leadership. (Doktora tezi). Electronic Theses and Dissertations for Graduate School.

Tran, Q., Tian, Y. ve Sankoh, F. P. (2013). The impact of prevalent destructive leadership behaviour on subordinate employees in a firm. American Journal of Industrial and Business Management, 3(7), 595.

Tepper, B. (2000). Consequences of abusive supervision. Academy of Management Journal, 43(2), 178-190. 
Thoroughgood, C. N., Hunter, S. T. ve Sawyer, K. B. (2011). Bad apples, bad barrels, and broken followers? An empirical examination of contextual influences on follower perceptions and reactions to aversive leadership. Journal of Business Ethics, 100 (4), 647-672.

Uymaz, A. O. (2013). Yıkıcı liderlik ölçeği geliştirme çalışması. İ.Ü. İşletme Fakültesi İşletme İktisadi Enstitüsü Yönetim Dergisi,24(75), 37-57.

Vliert, V. ve Einersan, E. (2008). Cultural construals of destructive versus constructive leadership in major world niches. International Journal of Cross Cultural Management, 8(3), 279-395.

Vredenburgh, D. veBrender, Y. (1998). The hierarchical abuse of power in work organizations. Journal of Business Ethics, 17(12), 1337-1347.

Yen, T. Q., Tian, Y. veSankoh, F. P. (2013). The impact of prevalent destructive leadership behaviour on subordinate employees in a firm. American Journal of Industrial and Business Management, 3(7) 595-600.

Yukl, G. (2018). Örgütlerdeliderlik. (Ş. Çetin, ve R. Baltacı, Çev.) Ankara: Nobel AkademikYayıncllı (2012).

Zapf, D., Einersan, S., Hoel, H. veVartia, M. (2003). Empiricial findings on bullying in the workplace and emotional abuse in the workplace. S. Einersan, H. Hoel, D. Zapf, and C. L. Cooper (Der.), International perspectives in research and practice içinde (s.103-126). London: Taylor and Francis.

\section{Kaynakça Bilgisi / Citation Information}

Maral, M.ve Çetin, M.(2021).Yıkıcı liderlik ile algılanan örgütsel engel arasındaki ilişkinin incelenmesi. OPUS-Uluslararası Toplum Araştırmaları Dergisi, 17(38), 5006-5041.DOI: 10.26466/opus.843064. 